\title{
CJPS
}

Nelli Semenova

Institute of Oriental Studies, RAS, Russian Federation

\section{SECURITY ISSUES IN TRANSPORT PROJECTS IN CENTRAL ASIA}

\begin{abstract}
China's Belt and Road Initiative (BRI), in which the countries of Central Asia play a key role, is becoming very attractive for the transit countries. China is investing heavily in the economic and infrastructure development of the region. Beijing pays attention not only to energy carriers but also plans to invest in transport and other industries. The BRI is a complex project that is still being finalized and many details are not yet clear. However, it seems that the Chinese government is doing its best to implement the aims of this initiative.

Since the collapse of the USSR and the independence of the Central Asian republics, there has been a noticeable change in the geography of the distribution of productive forces worldwide. In addition, new economic centers have emerged. All this has caused increased competition between transit countries for new routes in the transport services market in the region.

In this context, security issues for the implementation of Eurasian integration projects by China in the transport sector occupy one of the most important places on the agenda, since long-term operation and implementation are directly dependent on ensuring their security.

This research analyzes internal threats, instability conditions and security risks in Central Asia at national, sub-regional and regional levels. The contradictions between different actors create a basis for the emergence of conflict situations, the potential consequences of which need to be taken into account by China when planning and implementing major integration projects in the region.
\end{abstract}




\section{Key words}

Belt and Road Initiative, Silk Road Economic Belt, China, Central Asia, Eurasian integration, international security, transport projects

\section{Introduction}

China's Belt and Road Initiative (BRI), in which the countries of Central Asia play a key role, is becoming very attractive for the transit countries. China is investing heavily in the economic and infrastructure development of the region. Beijing pays attention not only to energy carriers but also plans to invest in transport and other industries. The BRI is a complex project that is still being finalized and many details are not yet clear. However, it seems that the Chinese government is doing its best to implement the aims of this initiative.

Since the collapse of the USSR and the independence of the Central Asian republics, there has been a noticeable change in the geography of the distribution of productive forces. In addition, new economic centers have emerged. All this has caused increased competition between transit countries for new routes in the transport services market in the region.

In this context, the security issues of the implementation of Eurasian integration projects of China in the transport sector occupy one of the most important places on the agenda, since the long-term operation and implementation of such projects are directly dependent on ensuring their security.

\section{Five threats to internal security}

The main security factor in Central Asia is the issue of the internal stability of the states of the region. We can identify at least five types of internal security threats that are found in all Central Asian countries:

1. The first one is the archaization of state institutions in the process of building nation-states after the collapse of the USSR. Elements of the Eastern despotism from past centuries have appeared in the political systems of these countries.

2. The second one is the weakness of democracy in combination with the clan principles used in the formation of government institutions and which determines the approach to solving socio-economic problems. This issue is worsened by the influence of Islamic radicalism which is expressed in the promotion of separatism and extremism and justifying terrorist methods of struggle (Morozov, 2009). 
3. The third is the confrontation between the values of liberal Western and traditionalist Eastern cultures (Omarov, 2007, p. 52) because the processes of modernization in Central Asia do not have internal roots and selfdevelopment sources, and therefore come into conflict with the traditions of Asian societies. This leads to a revival of traditionalist attitudes and the growth of mutual cultural alienation.

4. The fourth is the aggravation of the limitations of national economies as a result of the global economic crisis. Models of economic development based on raw material export do not ensure the prosperity of society and a high level of employment, and also have numerous flaws including a growing gap between rich and poor, corruption, and an unfair distribution of national wealth in favor of certain clans. This leads to an increase in labor migration, and social and cultural disintegration. Market mechanisms are developing poorly. Economic institutions, including financial ones, have a very low degree of sustainability. Economies are characterized by low competitiveness in regional and world markets, and a high degree of dependence on the import of goods or the export of raw materials (Semenova, 2012).

5. The fifth is the marginalization of the population, especially among the young, increases in wage gaps, a decline in the standard of living of the predominant part of the population - especially in rural areas, an increase in mortality, and intensified migration (Zviagelskaya, 2001).

\section{Prerequisites for possible conflicts}

A significant part of the economy of the countries of Central Asia belongs to criminal business, above all the shadow economy and drug trafficking.

The media sometimes exaggerate the possibility of events like an "Arab spring" in Central Asian states; however, expert opinion on this issue is divided. Some suggest that the situation in the countries of the region does not allow the prediction of a wave of revolutionary unrest. However, according to others, under the action of an organizing force, including an external one, unrest could flare up (Gasanaliev, 2011).

The state of political and social affairs at the subregional level in Central Asia is likely to change and unstable. Prerequisites for possible conflicts at the international level are due to the following factors:

- progressive fragmentation of countries in the region;

- dependence of Central Asian states on external subsidies; 
- inconsistency in foreign policy issues;

- the struggle for regional leadership;

- the clash of national, economic and resource interests.

\section{Determinants of instability in Central Asian states}

The basic conditions for the instability of the political situation in each of the Central Asian states can be considered.

Many experts express an opinion that the Republic of Kazakhstan has achieved a certain level of success in international politics and in its economy, and the probability of revolutionary processes there is one of the lowest in the region (Panfilova, 2011). However, political stability in Kazakhstan in many ways seems insubstantial. The following facts can illustrate this thesis.

Firstly, the political system of Kazakhstan can be described as authoritarian with a personalized rule, where all power is concentrated in the hands of a single person. Nursultan Nazarbayev, the former president and now officially "Leader of the Nation", is the main guarantor of political stability. Despite the transfer of power to Nazarbayev's successor, Kasym-Zhomart Tokayev, and holding early presidential elections in June 2019, Kazakstan has not developed a real mechanism for devolution of power which would guarantee its successful and smooth transfer in the future (Shibutov, 2012).

Secondly, the economy of Kazakhstan is highly vulnerable to global financial crises, with such consequences as the collapse of the real estate market, the bankruptcy of construction companies, and the growing problems of the banking system (Revyakin, 2009).

Thirdly, it is difficult for Kazakhstan to ensure border security. A relatively large territory and low population density does not allow for the effective protection of its external borders which, in turn, creates associated threats such as smuggling, illegal migration, and terrorist attacks.

And, finally, social tensions, ethnic conflicts and regular mass protests (Erzhanuly, 2012; Utro.ru News Agency, 2011) including protests against land reform (Dorr 2019).

Thus, despite the fact that Kazakhstan is the most successful country in the region, the condition of the state and society is far from being stable.

In general, the situation in Uzbekistan is under strict state control; the possibility of an "Uzbek spring" or a "color revolution", according to experts, is unlikely without external intervention (Panfilova, 2011). 
The following destabilizing factors in Uzbekistan can be identified:

1. The political regime in the country is a tough and authoritarian political regime, there is a hidden struggle of groups near to power, poor governance, the abolition of the independence of the branches of power, a high level of corruption and in practice an open system of selling government posts, a bloated bureaucratic apparatus including the National Security Service, which according to some data involves one million people (Grozin, 2012).

2. Lack of democratic freedoms, a complete ban on demonstrations and rallies, censorship; there is information about prisons for oppositionists and torture (Salih, 2010).

3. The economic crisis led to the bankruptcy of the largest industrial enterprises such as the Chkalov Tashkent Aviation Production Association and the Bukhara Textile Factory, as well as a rise in food prices.

4. The problems in the republic's agriculture are primarily related to the forced labor of rural residents, including their school-age children, in the cotton harvest on state-owned cotton fields.

5. Energy crisis: from December 1, 2009, to January 1, 2012, Uzbekistan suspended its membership of the Central Asia Power System. This decision, which was more political than economic nature, in damaged the electric power plants of Uzbekistan, and lowered its reliability and economic efficiency (Semenova, 2013, p. 132).

6. The demographic problem. The population of Uzbekistan is constantly growing; the republic has close to 30 million inhabitants (State Committee on Statistics of the Republic of Uzbekistan 2018). Jobs are created much more slowly than population growth, so the largest flow of labor migrants to Kazakhstan and Russia comes from Uzbekistan.

7. Raiding by the state. In Uzbekistan, under various pretexts mainly tax claims, the assets of foreign companies were nationalized (Aleksandrov, 2012; Fergana News Agency, 2012a). This can be attributed to the factors hindering the development of investment processes and, thereby, worsening the investment climate in the country (Birzhevoy \& Lider, 2012). Increased administrative interference and restrictions force businesses to keep a low profile (Minchenko, Petrov \& Kazantsev, 2013).

Kyrgyzstan had the painful experience of "color" revolutions in 2005 and 2010. The main problems in Kyrgyzstan are as follows:

1. Authority in the republic can be described as being in an acute political crisis. The change from Central Asian authoritarian governance to 
collective management did not lead to democratic changes. On the contrary, it caused a loss of control and contributed to the restoration of clan rule and increased corruption. In order to combat this, the form of government was changed from presidential to parliamentary. This, however, did not contribute to the process of bringing the republic out of a difficult situation. Kyrgyzstan lives with a constant confrontation between the clans of the north and south of the country. The role and influence of external factors on internal policy is becoming more noticeable (Malikov, 2012). The probability of revolutionary processes in Kyrgyzstan remains high.

2. The so-called "northern route," the world's largest drug route for the supply of opium from Afghanistan to Russia and further on to European countries, passes through the territory of Kyrgyzstan. A lot of hard drugs worth hundreds of millions of dollars are shipped through here every year (RIA Novosti 2012b). There is evidence of the connection of high-ranking officials and politicians with gambling and drug business (KomprInfo, 2011).

3. In 2018 , the amount of public debt of Kyrgyzstan exceeded $\$ 4.42$ billion, including external debt of $\$ 3.84$ billion, or $48.8 \%$ of country's GDP, and internal debt of $\$ 0.58$ billion (Regnum News Agency 2018). Despite the fact that Kyrgyzstan has substantial gold deposits, the country is experiencing serious economic difficulties such as a significant state budget deficit and economic stagnation, because corruption minimizes income from those deposits (Kurtov, 2006; RIA Novosti 2012a). For many years nationalization of the Kumtor gold deposit has been an issue. Now, it has become perhaps the main one in the programs of the Kyrgyz opposition (Prime News Agency, 2012; Deutsche Welle, 2015; Azattyk, 2018).

4. The reasons for the reduction of investment activity are the high level of political instability and the economic risks, including those related to the inviolability of property rights. Processes that have taken place concerning entrepreneurship, large businesses and the banking sector, indicate a violation of at least two criteria: repayment and the safety of funds (Regnum News Agency, 2011).

5. The industrial sector is stagnating. There have been no serious investment injections or the formation of serious project programs for industrial development.

6. The difficult socio-economic condition of the people of Kyrgyzstan. Most of the population is engaged in trade, intermediary, and household 
services, which are carried out under so-called "grey" schemes, therefore do not bring tax revenues to the state budget (Regnum News Agency, 2011).

7. The rise of nationalist sentiment as a result of the long-term deterioration of its social and economic situation, as well as a lack of an effective public policy to manage inter-ethnic relations. Since independence, the Kyrgyz Republic has not achieved significant progress in the formation of civic identity (Kuluev, 2012; Fergana News Agency, 2012b). As of January 1, 2018, the population of Kyrgyzstan was over 6.3 million (National Statistical Committee of the Kyrgyz Republic, 2019). Despite the fact that representatives of more than 80 nationalities live in the country (Xu, 2011), inter-ethnic relations remain tense.

Tajikistan is the poorest of the former Soviet republics. The current situation there can be described as unstable. In 1992-1997, the republic survived a five-year bloody civil war (Bushkov \& Mikulskiy 1996, p. 48). The system of political power is based on a peace agreement between the current leadership led by Emomali Rahmon and the United Tajik Opposition (UTO) reached in 1997.

Here is an incomplete list of the complex issues of modern Tajikistan:

1. Against a background of the catastrophic state of the economy and society, political affairs in the Republic of Tajikistan remain extremely complex. The country's leadership consistently pursues a policy of the complete monopolization of power over its economic assets. Tensions within the ruling elite are increasing. The likelihood of revolutionary processes in Tajikistan is the highest in the region (Panfilova, 2011).

2. Economic collapse. Industry of Tajikistan has almost entirely closed down with the exception of the aluminum plant and some hydropower facilities; the agricultural sector is unproductive.

3. The country is experiencing an extremely high level of unemployment and poverty of the majority of the population. The republic survives largely due to mass labor migration. According to the World Bank, up to 40 percent of Tajik citizens below the age of 30 are seeking work outside their own country (Popov, 2015). Tajikistan is consistently among the countries whose economies are most dependent on migration.

4. The Tajik-Afghan border is almost transparent for drug transit. The conflict in neighboring Afghanistan has a great impact on Tajikistan. Increased internal instability, associated with the activities of the armed opposition, is accompanied by an increase in the number of refugees, the supply of 
drugs and weapons from Afghanistan. Armed conflicts arise in certain regions and terrorist actions are conducted (Paramonov \& Strokov, 2013).

5. The permanent generator of tension is the pronounced fragmentation of the Tajiks into ethnic clan subgroups and sharp inter-clan contradictions (Panfilova, 2011).

Turkmenistan remains a closed country with no alternative political parties, media or other freedoms. The probability of revolutionary processes in Turkmenistan is estimated as low, if not zero (Panfilova, 2011). Turkmenistan has an absolute state monopoly on mass media (Freedom House, 2017; Reporters without borders, 2019).

According to meager data, it is known that the authorities continue a policy aimed at eliminating all non-Turkmen diaspora; the policy of so-called "tribal nationalism" causes an exacerbation of inter-tribal conflicts. On this basis, according to some experts, there is a possibility of a social explosion (Regnum News Agency, 2012b).

Corruption, poor education, government misuse of oil and gas revenues, and Ashgabat's reluctance to implement market reforms can be considered the most dangerous risks. Labor resources amount to 2.3 million. Unemployment is 60 percent. About 30 percent of the population live below the poverty line (Regnum News Agency, 2012a). Under President Saparmurat Niyazov, most economic statistics were classified as state secrets. President Gurbanguly Berdimuhamedow has created a state statistical agency, but most of the economic data remain unreliable.

The investment climate in Turkmenistan remains unfavorable, with a tendency to worsen. This happens for the following reasons: constant revisions of contractual obligations on the part of the Turkmenistan authorities, weak protection of investors' rights, features of the tax system, failure of the judicial system, high levels of corruption, etc.

Experts note that in Turkmenistan there are frequent cases of stealing a successful business (raiding) by individuals close to the authorities. Investment and commercial disputes between Turkmenistan and foreign companies mainly focus on three types of problem: non-payment of debts, disruption to the supply of goods and services, and revisions to contracts (Minchenko, Petrov, Zotin \& Romanenko, 2011, pp. 16-17, 23-59). 


\section{Political instability at the sub-regional level in Central Asia}

Inter-country relations between the Central Asian states are complicated by clashes based on a lack of coincidence of the political and economic interests of individual states.

Firstly, the issue of territorial demarcation of the Caspian Sea with the division of oil and gas resources as well as biological resources (Pustovoytova, 2011) between the five Caspian littoral states (Shustov, 2018).

Secondly, the region has a problem of water and hydropower resources (Rudov, 2011; Shustov, 2009).

Thirdly, in each of these states, there are intractable territorial conflicts that arose after the collapse of the USSR such as controversial issues of border delimitation in the Fergana Valley between Tajikistan, Kyrgyzstan, and Uzbekistan (Shustov, 2016). Large diasporas from these countries live on "other" sides of the borders in enclaves (Central Asian News Agency, 2012). For example, in the opinion of a certain part of the elite of Tajikistan, the cities of Bukhara and Samarkand inhabited by Tajiks, were "unfairly" inherited by Uzbekistan as a result of administrative and territorial reform in the USSR in 1924.

\section{Conclusion}

It can be stated that the political situation in the region reflects a wide range of intra-regional and inter-country tensions directly related to geopolitics, transport, investment and energy, including attempts to use the resources of Central Asia to obtain additional benefits in the regional rivalry in this subsystem of international relations.

Risks and threats to security at the regional level are characterized primarily by the progressive disunity of the countries of Central Asia. This is due to the political ambitions of the ruling elites who are guided by narrow nationalist interests in intergovernmental relations. In each state in the region, the political elites have an oversimplified view of national security and put it above regional security. Thus, they deprive themselves of the opportunity to ensure their own, so jealously guarded, national security, especially in terms of energy or transport. Another consequence of this situation is the competition of the countries of the region in the investment sphere.

This is not a complete list of the variety of threats to the regional security of transport projects in Central Asia. It is difficult to underestimate each of these 
factors and rank them according to the degree of risk. However, it is clear that these contradictions create the basis for the emergence of conflict situations, the potential consequences of which need to be taken into account when planning and implementing large integration projects such as China's Belt and Road Initiative (BRI).

\section{REFERENCES}

Aleksandrov, I. (2012, Oct 2). Tashkent capture. Rossiyskaya gazeta. Retrieved from http://www.rg.ru/2012/10/02/zahvat.html/

Azattyk. (2018, Jul 18). Initiative to nationalize the Kumtor mine. Retrieved from https:// rus.azattyk.org/a/kyrgyzstan-kumtor-nationalization/29373367.html

Birzhevoy Lider. (2012, Jun 8). Why are investors wary of investing in Uzbekistan? Retrieved from http://www.profi-forex.org/novosti-mira/novosti-sng/uzbekistan/ entry1008125067.html

Bushkov, V. I., \& Mikulskiy, D. V. (1996). Anatomiya grazhdanskoy voyny v Tadzhikistane (etno-sotsialnye protsesy i politicheskaya borba 1992-1995). Moskva: Institut etnologii i antropologii RAN, Institut prakticheskogo vostokovedeniya [Anatomy of the civil war in Tajikistan (ethno-social processes and political struggle 1992-1995). Moscow: Institute of Ethnology and Anthropology of the Russian Academy of Sciences, Institute of Practical Oriental Studies].

Central Asian News Agency. (2012, Apr 19). The confrontation of Tajikistan and Uzbekistan did not arise yesterday. Retrieved from http://www.ca-news.org/news:9480 Deutsche Welle. (2015, Apr 9). Kyrgyzstan: Political battles around the Kumtor gold deposit. Retrieved from https://www.dw.com/ru/киргизия-политические-баталиивокруг-месторождения-золота-кумтор/а-18372896

Dorr, S. (2019, Apr 16). What is the Kazakh regime learning from citizen protests? Open Democracy. Retrieved from https://www.opendemocracy.net/en/odr/what-kazakhregime-learning-citizen-protests/

Erzhanuly, S. (2012, Jul 12). Reflections at the entrance. Who and why destabilizes the situation in Kazakhstan? Russians in Kazakhstan. Retrieved from http://www. russianskz.info/3344-razmyshleniya-u-podezda-akordy-kto-i-zachem-destabiliziruet-situaciyu-v-kazahstane.html

Fergana News Agency. (2012a, Jul 18). Jackals Day, or what happened to MTS in Uzbekistan. Retrieved from http://www.fergananews.com/article.php?id=7429

Fergana News Agency. (2012b, Jun 7). Assessing the circumstances and chronology of the tragic events of May-June 2010 in the cities of Osh, Jalal-Abad, certain districts of Osh and Jalal-Abad regions. Retrieved from http://www.fergananews.com/article. php?id=7389 
Freedom House. (2017). Freedom of the Press 2017. Retrieved from https://freedomhouse.org/report/freedom-press/freedom-press-2017

Gasanaliev, M. (2011, Sep 16). The political situation in the countries of Central Asia may become complicated over time - experts. Kavkaz.ge. Retrieved from http://kavkaz. ge/2011/09/16/politicheskaya-situaciya-v-stranax-centralnoj-azii-so-vremenemmozhet-oslozhnitsya-eksperty

Grozin, A. V. (2012, Aug 24). Uzbekistan: neither gold, nor cotton brings joy. Institute of the CIS Countries. Retrieved from http://www.materik.ru/problem/detail. php?ID=15381

KomprInfo. (2011, Oct 22). Up to 70 percent of heroin traffics to Russia through Kyrgyzstan, in which there is a merging of power with drug mafia. Retrieved from http:// www.informacia.ru/content/1553

Kuluev, A. (2012, Sep 28). Assessing autumn political intrigues and changes in the political situation in Kyrgyzstan. Central Asian Portal. Retrieved from http://www. ca-portal.ru/article: 3800

Kurtov, A. (2006, Sep 18). Who attracts the brilliance of Kyrgyz gold? Political News Agency-Kazakhstan. Retrieved from http://www.apn.kz/publications/article5878. htm

Malikov, K. (2012, Sep 4). An expert community does not exclude aggravation of the political situation in Kyrgyzstan and around it. Center for Strategic Assessment and Forecast. Retrieved from http://csef.ru/ru/oborona-i-bezopasnost/340/ekspertnoesoobshhestvo-ne-isklyuchaet-obostreniya-politicheskoj-situaczii-v-kyrgyzstane-ivokrug-nego-k-oseni-2012-goda-3578

Mamontova, D. (2012, Sep 25). In Kyrgyzstan, the state balance has gold deposits with proven reserves of 430 tons. K-News. Retrieved from https://knews.kg/2012/09/25/vkyirgyizstane-na-gosbalanse-imeyutsya-mestorojdeniya-zolota-s-razvedannyimizapasami-v-430-tonn/

Minchenko, E., Petrov, K., \& Kazantsev, A. (2013). Investment potential of Uzbekistan: a report. International Institute for Political Expertise. Retrieved from http://www. minchenko.ru/netcat_files/File/Uzbekistan\%20issledovanie\%2015_07_full.pdf

Minchenko, E., Petrov, K., Zotin, A., \& Romanenko, Yu. (2011). Investment potential of Turkmenistan: political risk analysis. International Institute for Political Expertise. Retrieved from http://www.stratagema.org/netcat_files/File/Last_Rus_sm.pdf

Morozov, Yu. V. (2009). Vliyanie politiki vedushchikh gosudarstv mira na transformaciyu voenno-politicheskikh otnosheniy v Tsentralnoy Azii. Institut SShA i Kanady RAN, Rossiya $i$ Amerika $v$ XXI veke 2 [The influence of the policy of the leading states of the world on the transformation of military-political relations in Central Asia. Institute for the USA and Canadian Studies RAS, Russia and America in the 21st century 2]. Retrieved from http://www.rusus.ru/?act=read\&id=144

National Statistical Committee of the Kyrgyz Republic. (2019). Population. Retrieved from http://www.stat.kg/ru/statistics/naselenie/ 
Omarov, N. (2007). "Stoletye globalnoy alternativy" dlya formirovaniya novogo prostranstva bezopasnosti v postsovetskoi Evrazii ["A century of a global alternative" for the forming a new security space in post-Soviet Eurasia]. Bishkek, 2007. Panfilova, V. (2011, May 13). A revolutionary caftan for Central Asia. Nezavisimaya gazeta, 13 May. Retrieved from http://www.ng.ru/cis/2011-05-13/1_asia.html

Paramonov, V. V., \& Strokov, A. V. (2013). Assessing the political situation in Tajikistan. Central Asia. URL: http://www.ceasia.ru/politika/k-otsenke-politicheskoy-situatsiiv-tadzhikistane.html

Popov, D. S. (2015, May 29). Labor migration from Tajikistan in figures. Russian Institute for Strategic Studies. Retrieved from http://riss.ru/analitycs/17465/

Prime News Agency. (2012, Sep 20). The "Polyus" and the "Norilsk Nickel" are interested in the gold of Kyrgyzstan. Retrieved from https://1prime.ru/News/20120920/757281082. html

Pustovoytova, E. (2011, Nov. 13). Battle of the Caspian: Colossal oil resources of the lakesea were the subject of the struggle of the five countries. Stoletie.ru. Retrieved from http://www.stoletie.ru/geopolitika/bitva_za_kaspij_2011-11-03.htm

Regnum News Agency. (2011, Jul 8). The economist spoke about the economic results of the "post-revolutionary" Kyrgyzstan. Retrieved from http://www.regnum.ru/news/ kirghizia/1423225.html

Regnum News Agency. (2012a, May 5). US CIA: The general prospects for the near future of Turkmenistan look dismal. Retrieved from http://regnum.ru/news/1528037. html\#ixzz2C2pVqMQL

Regnum News Agency. (2012b, Aug 13). The security sweep in Turkmenistan: Russian passport holders are forced to change citizenship. Retrieved from http://www.regnum.ru/news/polit/1560740.html

Regnum News Agency. (2018, Jul 9). Kyrgyzstan's external debt exceeds 242 billion rubles. Retrieved from https://regnum.ru/news/2445201.html

Reporters without borders. (2019). Press Freedom Index 2019. Retrieved from https:// rsf.org/en/ranking

Revyakin, S. (2009). The impact of the global financial crisis on the economy of Kazakhstan. KazEnergy, 4(30-31). Retrieved from http://old.kazenergy.com/4-30-312009/3589-2012-01-19-09-45-06.html

RIA Novosti. (2012a, Nov 3). In Kyrgyzstan, again rally, this time for the nationalization of the mine. Retrieved from http://ria.ru/world/20121003/765322014.html

RIA Novosti. (2012b, Jul 19). The leadership of the anti-drug service of Kyrgyzstan retired. Retrieved from http://ria.ru/world/20120719/703628341.html

Rudov, G. A. (2011). Problemy i slozhnosti razvitiya gosudarstv Tsentralnoy Azii [Problems and difficulties of development of Central Asian states]. Obozrevatel-Observer, 4, 101-109.

Salih, M. (2010, Dec 10). The situation in Uzbekistan reminds the Soviet Union before the collapse. Umma 42. Retrieved from https://www.umma-42.ru/news-1625.html 
Semenova, N. K. (2012). Kitayskiy energeticheskiy vector: znachenie SHOS i bezopasnost v Tsentralnoy Azii. Vostochnaya analitika 3. Institut vostokovedeniya RAN [Chinese energy vector: the significance of the SCO and security in Central Asia. Eastern Analytics 3. Institute of Oriental Studies RAS], 144-160.

Semenova, N. K. (2013). Energeticheskaya strategiya Kitaya: ugrozy i riski bezopasnosti v Tsentral'noy Azii. Vestnik NGU. Vypusk 4: Vostokovedenie. Izdatelstvo SO RAN. Novosibirsk [China's energy strategy: threats and security risks in Central Asia. Bulletin of the Novosibirsk State University. Issue 4: Oriental Studies. Novosibirsk: Publishing House of the Siberian Branch of the RAS], 124-132.

Shibutov, M. (2012, Aug 8). Ancestral imbalances in Astana will force the regional elite to exacerbate the situation. Regnum News Agency. Retrieved from http://www. regnum.ru/news/1559128.html

Shustov, A. (2009). Tajik-Uzbek conflict: winter aggravation. Strategic Culture Foundation, 27 December. URL: https://www.fondsk.ru/news/2009/12/27/9917-9917.html

Shustov, A. (2016, Oct 17). Conflict triangle of Central Asia. The situation on the borders between Kyrgyzstan, Uzbekistan and Tajikistan remains difficult. CentrAsia. Retrieved from https://centrasia.org/newsA.php?st=1476655380

Shustov, A. (2018, Aug 14). “The Constitution of the Caspian”: how to divide the Caspian Sea. Eurasia Expert. Retrieved from http://eurasia.expert/konstitutsiya-kaspiya-kakrazdelili-kaspiyskoe-more/

State Committee on Statistics of the Republic of Uzbekistan. (2018). Demographic situation. Retrieved from https://stat.uz/uploads/docs/Demografiya-yan-iyun-18-RU.pdf

Utro.ru News Agency. (2011, Dec 16). A riot broke out in Kazakhstan. Retrieved from http://www.utro.ru/articles/2011/12/16/1017528.shtml

$\mathrm{Xu}, \mathrm{X}$. (2011, Apr 15). Trends in the development of the political situation in Kyrgyzstan. A view from Beijing. East Time. Retrieved from http://easttime.ru/analitic/3/9/950. html

Zviagelskaya, I. D. (2001). K voprosu ob ugrozah bezopasnosti v Tsentralnoy Azii. NII Sotsialnyh system MGU im. M.V. Lomonosova [On the issue of security threats in Central Asia. Research Institute of Social Systems, Lomonosov Moscow State University]. Retrieved from http://www.niiss.ru/05.shtml 